\title{
Form(s)-of-Life. Agamben's Reading of Wittgenstein and the Potential Uses of a Notion ${ }^{1}$
}

\author{
Matias Leandro Saidel ${ }^{2}$
}

\begin{abstract}
Giorgio Agamben and Ludwig Wittgenstein seem to have very little in common: the former is concerned with traditional ontological issues while the latter was interested in logics and ordinary language, avoiding metaphysical issues as something we cannot speak about. However, both share a crucial notion for their philosophical projects: form of life. In this paper, I try to show that, despite their different approaches and goals, form of life is for both a crucial notion for thinking ethics and life in-common. Addressing human existence in its constitutive relation to language, this notion deconstructs traditional dichotomies like bios and zoé, the cultural and the biological, enabling both authors to think of a life which cannot be separated from its forms, recognizing the commonality of logos as the specific trait of human existence. Through an analogical reading between both theoretical frameworks, I suggest that the notion of form-of-life, elaborated by Wittgenstein to address human production of meaning, becomes the key notion in Agamben's affirmative thinking since it enables us to consider the common ontologically in its relation to Human potentialities and to foresee a new, common use of the world and ourselves.
\end{abstract}

KEYWORDS: Agamben. Wittgenstein. Form-of-Life. Potentialities. Language. Community.

\section{INTRODUCTION}

[...] every thought can be classified according to the way in which it articulates the question of the limits of language [...] (AGAMBEN, Infancy and History, p. 4).

At first sight, Giorgio Agamben and Ludwig Wittgenstein seem to have very little in common: the former is concerned with ontological, aesthetic, ethical and political issues and is famous for his reflections on biopolitics while

\footnotetext{
${ }^{1}$ A first draft of this essay was prepared for a Seminar on Language and Politics, taught at Cornell University by Jason Frank in 2010. I would like to thank Laura Bazzicalupo, Davide Tarizzo, Ingrid Diran, Jason Frank, Bruno Bosteels, Massimo de Carolis and Kevin Attell who generously read and commented this paper at that stage.

${ }^{2}$ Academic affiliation: Consejo Nacional de Investigaciones Científicas y Técnicas — Universidad Católica de Santa Fe — Universidad del Salvador. E-mail: matiaslsaidel@gmail.com
} 
the latter was interested in logics and, later, ordinary language, discarding most traditional problems of metaphysics. However, both share a notion that is crucial for their philosophical projects: form of life.

In this paper, I will try to show that, despite its ambiguity, form of life is for both a crucial notion for thinking the Common, the shared existence of human beings in its constitutive and ethical relation to language. Reading Wittgenstein's Tractatus together with Heidegger's Sein und Zeit, Agamben will try to introduce this concept in his ontological framework, linking it to ethics and the question of anthropogenesis. Accordingly, he will preserve the ambivalence we find in Wittgenstein between the approach of "natural history" and a form of cultural constructivism which, in his view, is able to undo the split between the biological and the spiritual, life and its forms, nature and culture, in order to think their point of intersection. Agamben's project tries precisely to deactivate a form of biopower which articulates and separates these polarities in a relation of exclusive inclusion.

In what follows, I first comment on the concept of form-of-life in Wittgenstein's time in order to suggest a possible source of its ambivalence in its previous uses in the Germanic context. Then, I highlight some common features between both authors and comment on some relevant Agamben's references to Wittgenstein. Later, I explore the ethical and political implications of the notion in Giorgio Agamben in its opposition to bare life. I try to show that this is directly linked to his ontology of inoperativeness, use, and profanations.

Therefore, this article will clearly depart to some extent from Wittgenstein's reflections on ordinary language and will not try to show a direct, genealogical link between both authors in the use of this notion. Through an analogical reading, it will rather focus on the appropriation of this concept by Agamben and its possible uses to think the common in our time.

Lebensform oder Lebensformen?

The notion of "form of life" appears only a few times in Wittgenstein's published writings. ${ }^{3}$ However, despite the unclear meaning of the notion

\footnotetext{
3 "Form of life" appears as such in Wittgenstein's published writings only in $\$ 19, \$ 23, \S 241$, and in p. 174 and p. 226 of the Philosophical Investigations (1953), in $\$ 358$ of On Certainty (1972), in the Remarks on the foundations of mathematics (1956) VII: 47 and Remarks on philosophy of psychology (1980) $\$ 630$ (GARVER, 1994; KISHIK, 2008). Nonetheless it appears many times in his Nachlass notes in three different fashions, as: Lebensform, Lebensformen and Form des Lebens. See wittgensteinsource.org
} 
(HUNTER, 1968), Wittgenstein scholars have agreed from the outset that this is the most significant concept in his philosophy (GIER, 1980). Readers such as Malcolm (1954) and Cavell (1962) perceived it as crucial, and, at the same time opaque, even impenetrable (KISHIK, 2008), since the author did not use it in a technical way and did not provide any definition of it. ${ }^{4}$ At the same time, this notion enabled a dialogue between Wittgenstein and a broader philosophical, anthropological and political tradition.

For Wittgenstein, form of life is crucial to understand the way in which statements acquire meaning as part of language-games, bringing language from the metaphysical realm of logic to its everyday use, and also, we may add, de-centering the psychological subject. Separating meaning from a subjective intention, Wittgenstein stressed the role of the public use of language and its criteria in grasping the meaning(fulness) of propositions. For him, the picture of a correspondence between things and words paves the way for skepticism, as it is related to the search for a fully logical language referring only to states of affairs which is far from the way language works. In his Philosophical Investigations (1953) this stance is criticized as a product of a misunderstanding of the way we use language which presupposes what is in turn to be investigated. In this sense, meaning is related to the different language games we play, which are made of both discursive and non-discursive practices and are embedded in a form of life. ${ }^{5}$ But how can we understand this concept in the first place?

This ambiguity of Lebensform(en) can be traced back to its emergence in the Germanic realm, acquiring cultural and naturalistic meanings in different uses. According to Padilla and Gaffal (2012), the notion appears first in the Grimm Brothers dictionary in 1838 addressing "[...] the physical condition of heavenly bodies" and "[...] a kind of poetry of mental urge" (PADILLA; GAFFAL, 2012, p. 8). Then, in 1905 A. Wechsler (W. Fred) wrote Lebensform: Anmerkungen über die Technik des gesellschaftlichen Lebens [Form of life: Remarks on the Technique of Societal Life], where Lebensform refers to a style of life and describes the regularities of social, everyday life in modern societies (PADILLA; GAFFAL, 2012, p. 9).

\footnotetext{
${ }^{4}$ In fact, he hardly ever provides definitions, coherently with his critique of "craving for generality".

${ }^{5}$ As Garver (1994) points, although many scholars cite it in the plural, in an already culturalist interpretation of the term, it only appears once in that way in Philosophical Investigations.
} 
Form of life acquires a different meaning in Rudolph Kjellén's ${ }^{6}$ Staten som livsform (1916) [The State as a Living Form] which stressed the biological dimension of the notion, ${ }^{7}$ pointing that states are not fixed juridical entities but dynamic living organisms competing on the international arena. Published in German in 1917, it had a great influence in this realm. Indeed, the term was appropriated by Haushofer and linked to Ratzel's notion of Lebensraum, influencing later Nazi theory of the state and foreign policy.

Some years later, Eduard Spranger published Lebensformen: Geisteswissenschaftliche Psychologie und Ethik der Persönlichkeit (1921) [Forms of life: Science-of-the-Spirit Psychology and Ethics of Personality] in which inspired by his Professor Dilthey's assertion of the autonomy of the sciences of the spirit (Geisteswissenschaften) — he tried to elaborate a geisteswissenschaftliche psychology in which Dilthey's concept of Verstehen allows transcending the immediate consciousness of the individual's psyche and grasping mental structures as meaningful in cultural relations, while providing objectively valid knowledge. Spranger proposed six basic ideal-types of individuality, pointing that different human forms of life are determined by dominant commitments and activities. Hence, he emphasized the spiritual and psychological dimension and the plurality of forms of life. Likewise, the expression appears frequently in the Austrian psychotherapist Alfred Adler's The meaning of Life (1933), to describe learning processes in the human psyche during the first years of life that shape the person's mentality (PADILLA; GAFFAL, 2012, p. 10).

Also in O. Spengler's The Decline of the West (1918-1923), Lebensform characterizes a civilization, a psychological and sociocultural context in which the individual becomes aware of his situation. Spengler understood cultures as relatively closed entities in which people share a world-view.

Padilla \& Gaffal (p. 13) note that there was another book accessible for Wittgenstein at Cambridge Library: Hermann Ammann's volumes on human speech. The second volume (1928) is entitled Lebensform und Lebensfunktionen der Rede [Form of Life and Vital Functions of Speech].

\footnotetext{
${ }^{6}$ Kjellén was a Swedish geographer, political scientist and politician who, inspired by Friedrich Ratzel (author of the later ominous concept of Lebensraum), coined the term Geopolitics and also national socialism in 1910, well before the emergence of the NSDAP. His ideas are analyzed in R. Esposito's genealogy of biopolitics (2004), together with those of Binding, Hahn, and Dennert, all of which theorized about the state in an organicist fashion in the 1920s. For an account of Kjellen's book, unpublished in English, see TUNANDEN (2001).
}

${ }^{7}$ The first German edition of this text appeared in 1917, and had a great impact in this realm. 
According to Ammann, forms of life are expressed through speech acts which social character determines the nature of propositions.

As we can see, this concept was in the air in Wittgenstein's cultural milieu, assuming different meanings. While Kjellén's notion leads to biopolitical thinking, the other sources seem to enable a cultural one. We may add that Oswald Spengler's ideas imply a mixture of both positions, enabling a reading of cultures as social organisms. No wonder, then, that the ambiguity we find from the very beginning in the notion of Lebensform will also appear in Wittgenstein's elaborations and will be debated by Wittgenstein scholars.

Interpreters are divided between those who read it in the singular (Hunter; Garver) ${ }^{8}$, as form of life, stressing the naturalistic dimension, referred to "biological, organic or natural forms of life", and those who read it as "forms of life" (Whittaker) pointing to a cultural approach, implying "cultural, social or communal forms of life". The first view is that of natural history, separating different types of animals (CAVELL, 1989; GARVER, 1994). The second affirms that forms of life are meant to distinguish between different kinds of human beings, and they account for our cultural differences. "Where the first view focuses on the unity and necessity of the human form of life as a given that persists over time, the opposite view emphasizes the diversity and contingency of different human forms and the ability to alter such conventions" (KISHIK, 2008, p. 121-22). ${ }^{9}$

The first stance draws on assertions in which Wittgenstein maintains that chatting or recounting are as much a part of our natural history as walking or eating, $(1958, \$ 415)$ or that “[...] only those who have mastered

\footnotetext{
${ }^{8}$ According to Garver, it is likely that Wittgenstein used form of life to refer sometimes to culturally variant - rather than biological - patterns of living, but first and foremost Wittgenstein's forms of life are those of natural history: bovine, piscine, canine, reptilian, human, feline, leonine, etc. He also maintains that the assumption that Wittgenstein spoke about a plurality of human forms of life is unnecessary and misleading.

${ }^{9}$ In this sense, Kishik also refers to a divide between "relativism" and "anti-relativism". Relativists (Hilm, Rorty, Emmett) think that "[...] a form of life is a form of culture, and they tend to claim that it is inviolable, that it cannot be criticized, and is never superior or inferior to other forms of life". Antirelativists (Lear, Hinman, Rudder-Baker) "[...] tend to see a coherent form of life that goes beyond our differences by means of a shared reason or rationality". He also stresses the opposition between a conservative and a liberal point of view. Conservatives take the existing form of life as a solid entity that needs to be protected from rapid changes while liberals take the form of life to be a much more fluid entity that can and should be mended. Where some resist any attempt to shape a form of life, others take the force to shape it to be the essence of politics. While some think it as a-political, others take it to be political power par excellence (KISHIK, 2008, p. 122)
} 
the use of a language" can hope or deceive and that "[...] the phenomena of hope are modes of this complicated form of life" (1958, p. 174). From this, Garver concludes that when Wittgenstein discusses differences it is not among individuals, nations or cultures but among human activities and uses of language, and that there is a single form of life common to all humankind (1994, p. 267).

Those who read it as form(s)-of-life, point to the way in which a particular context shapes the language-games we are able to play and to the plurality of forms of life that exist. From passages like the following, many conclude that "forms of life" speaks of a relatively closed linguistic universe, such as a "culture":

2.41 "So you are saying that human agreement decides what is true and what is false?"-It is what human beings say that is true and false; and they agree in the language they use. That is not agreement in opinions but in form of life. [...] "What has to be accepted, the given, is -so one could say-forms of life". (1958, p. 226).$^{10}$

Assuming that Wittgenstein was familiar with Spranger's book which, according to Gier sold 28.000 copies_-, Janik and Toulmin speak of "[...] all the alternative Lebensformen [as] all the possible human styles of thought, character and language" (1973, p. 231 apud GARVER, p. 247). On the contrary, Garver maintains that "[...] what is at stake in the last three passages $(1958, \$ 241$; p. 174 ; p. 226), where agreement in form of life is invoked as a stopping point of inquiry, are such activities as naming colors, measuring, doing mathematics, hoping and grieving" and it " $[\ldots]$ is absurd to imagine that any of these characteristically human activities depend on having some particular life-style or "form of life" in the sense of Spranger" (p. 247-48)

In our view, the division needn't be read as an exclusive alternative. Indeed, there are also scholars who recognize a first divide between human and other forms of life and a plurality of forms of life within humanity

\footnotetext{
${ }^{10}$ Hardt \& Negri maintain that the "emergence of the common... is what has attracted so many authors to the epistemological and political possibilities opened by Ludwig Wittgenstein's notions of language games and forms of life". Commenting on the cited passage, they conclude: "First, by grounding truth in language and language games he[...] locates it on the fluid, changeable terrain of practice[...] Second, after destabilizing truth he restores to it a consistency. Linguistic practice is constituent of a truth that is organized in forms of life" (2009, p. 121-122).
} 
(Gier; O'Connor). ${ }^{11}$ For instance, Wittgenstein affirms that " $[\mathrm{t}]$ he common behavior of mankind is the system of reference by means of which we interpret an unknown language” (1958, \$206). For O’Connor it means that “[w]ide cultural variation and divergence from common practice, rather than serving as evidence against there being a range of behaviors common to humankind, actually shows how much do we have in common" (2008, p. 75).

As Gier states in a careful reading of Wittgenstein oeuvre, “[...] a common biology is a necessary but not sufficient condition for meaningful human actions" and "Lebensformen are therefore primarily the formal conditions, the patterns in the weave of our lives, that make a meaningful world possible". Following this view, we might read Wittgenstein's idea that "[...] to imagine a language means to imagine a form of life" $(1958, \$ 19)$, as meaning that language is part of an activity and there are multiple possible language games within a form of life, which are permanently evolving.

But how many kinds of sentence are there? [...] There are countless kinds $[\ldots]$ And this multiplicity is not something fixed, given once for all; but new types of language, new language-games, as we may say, come into existence, and others become obsolete and get forgotten... Here the term "language-game" is meant to bring into prominence the fact that the speaking of language is part of an activity, or of a form of life. $(1958, \S 23)$.

According to Gier, then, form of life has a transcendental function, being the condition of possibility of human communication. Similarly, Kishik maintains that the problem may not be in the concept itself but in the dichotomies that we use to think in philosophy, which do not work here: Form of life enables things that seem incongruent to coincide, deactivating our dualistic divisions. He also stresses that this concept is at the crossroads of early and late Wittgenstein, and between analytic and continental philosophy. This interpretation is already an Agambenian one, to which we will turn in the next sections.

\footnotetext{
${ }^{11}$ According to O'Connor (2008, p. 70): “One way to read Wittgenstein's use of 'form of life' is to pick out what biologists call a natural kind... There is one human form of life having a natural history and is therefore distinct from all other forms of life found in the world. For Wittgenstein, the natural history includes not only what might be called biological dimensions, but social and cultural ones as well. These dimensions produce incredible diversity within this shared form of life. Wittgenstein links forms of life with natural history by comparing the activities and capacities of human and nonhuman animals... Wittgenstein is not seeking the criterion that absolutely distinguishes human living from other forms of living".
} 


\section{WORLDLY EXISTENCE, LANGUAGE, ETHICS, COMMUNITY AND FORM-OF-LIFE}

In our view, both Agamben and Wittgenstein will try to overcome traditional dichotomies of Western thought, in order to enable another approach to thought, language, world and ethics. Both focus on the implications of language-use for human beings. Assuming we are 'the fly in the bottle' of which Wittgenstein speaks, Agamben maintains that this bottle is language and we can only see the world through its glass, but not the glass itself (1985). Like Wittgenstein, he also wants to disenthrall us from a picture of our language produced by traditional metaphysics that operates through dichotomies and also presuppose a negative foundation for language that he calls the Voice (1982). However, whereas Wittgenstein dismissed in his last writings any metaphysical matter as a product of a misuse of language by philosophers, or by misunderstandings due to a certain picture of our language that holds us captive ${ }^{12}$, Agamben will try to think a new ontology.

From the very beginning of his reflection, Agamben reflects on the pure fact of communication and the ethical implications of the very existence of language. Instead of analyzing the language games we play, he interrogates the relationship between human existence and the existence of language. However, Agamben maintains that Wittgenstein had a great influence in his own "method" by which "[...] philosophical problems become clearer as we ask for the meaning of words" (1999, p. 177). ${ }^{13}$ In this sense, one of the main concerns for Agamben is the meaning of "I speak". To analyze that matter, he delves into the "Ethical" section (6.4) of the Tractatus where Wittgenstein maintains that the sense of the world is outside the world, that God does not reveal itself in the world, and "the mystical" is not how the world is but that there is a world. ${ }^{14}$

\footnotetext{
${ }^{12}$ In a similar sense, Nietzsche wrote: "Ich fürchte, wir werden Gott nicht los, weil wir noch an die Grammatik glauben [...]” (1888: \$5) ["I fear we do not get rid of God, because we still believe in grammar [...]" (1888, p. 16)].

${ }^{13}$ Until his last books on form-of-life (2011) and Oath (2008), Agamben's quotations of Wittgenstein focused on the "first Wittgenstein" to think the relationship between language, world and ethics. Many of his references to Wittgenstein are brief and en passant, so we will focus on those relevant for our argument. References can be found at least in Agamben (1978, 1982, 1990, 1993, 1996b, 1999, 2011).

${ }^{14}$ In this way, he avoids the transcendent dimension as that of which we cannot speak - and thereof we must be silent. Later, as we have seen, in Philosophical Investigations, together with his annulment of any possibility of meta-language, Wittgenstein establishes language-games as the main concern for philosophy, which leaves everything as it is: its task is therapeutic, it can clarify some deadlocks produced by our use of language, but cannot solve them.
} 
In an addendum to the French version of Infancy and History published in 1989, speaking of the project of a book he had not written about voice and ethics, Agamben maintains that ethics are possible because of the scission between voice and language, because phoné and logos are not necessarily articulated as our tradition has always thought. He proposes an experimentum linguae by which one can think of the existence of language as such, which enables him to envisage a community without presuppositions. "The only content of the experimentum is that there is language; we cannot represent this, by the dominant model in our culture, as a language" (1978, p. 9). Agamben maintains that he takes this experimentum from Wittgenstein's public lecture on Ethics for the Association of 'the Heretics' (1929):

And now I shall describe the experience of wonderment before the existence of the world, with these words: the world thus is experienced as a miracle. I am now tempted to say that the correct expression in language for the miracle of the existence of the world, albeit as expressing nothing within language, is the existence of language itself. ${ }^{15}$

Agamben immediately adds:

Let us try to follow through Wittgenstein's experiment, by asking ourselves: if the most appropriate expression of wonderment at the existence of the world is the existence of language, what then is the correct expression for the existence of language? The only possible answer to this question is: human life, as ethos, as ethical way. The search for a polis and an oikia befitting this void and unpresupposable community is the infantile task of future generations (1978, p. 10).

As we can see, according to Agamben, language is intimately related to our ethos — both habit and dwelling — our human form-of-life, and infancy is the transcendental condition of our entrance (or not) into language that enables us to think a community with no presuppositions, in which singular beings are exposed to the very fact of communicability. At the same time, the fact that Wittgenstein referred to metaphysical inquiry as something beyond our reach, does not imply he considered it as pure nonsense. For instance, in that conference he declared to understand what Heidegger meant when

${ }^{15}$ I use here Agamben's version, which differs slightly from the original. 
discussing metaphysical notions like Angst [fear, anxiety] and Sein [Being]. ${ }^{16}$ Wittgenstein maintains that ethical speech runs against the boundaries of language (1929), as in the amazement that something like the world or the sky exists or in the experience of feeling absolutely safe, where any significant denotation fails (also in AGAMBEN, 1993a, p. 70). For Wittgenstein, the difficulty emerges when we try to express ethics or this amazement in a theoretic or descriptive language in which these expressions make no sense (VOLPI, 2006, p. 213-21).

In this sense, Agamben reads the abovementioned passage of the Tractatus maintaining that what Wittgenstein calls "the mystical" is not a psychic reality beyond language, but infancy: the only possible non-linguistic (and so pre-subjective) experience for human beings as the transcendental condition of the acquisition of language. What Agamben is trying to do is to turn what has been thought in Cacciari's reading of Wittgenstein as a negative foundation (the mystical, sygetics) as a positive condition of pure potentiality he names infancy. At the same time, in this passage we can understand what is specifically human for Agamben — and, I think also for Wittgenstein: differently from the animal voice (phoné), and from the Aristotelian assertion that man is the being that has language, Agamben points out that humans have to appropriate their own linguistic essence. The experience of infancy names a pure potentiality in which the Homo sapiens can become human or fail to do so. It is the unspeakable as the condition of possibility of speaking. By entering language, the human animal also enters history. It means that "human nature" is already split in its origin. In this sense, following Benveniste, Agamben maintains that it is not language in general that marks out the human being from the rest of the animals but the split between language and speech, semantic and semiotic:

\begin{abstract}
Animals do not enter language, they are already inside it. Man, instead, by having an infancy, by preceding speech, splits this single language and, in order to speak, has to constitute himself as the subject of language - he has to say $I$. Thus, if language is truly man's nature... then man's nature is split at its source [...] It is infancy, it is the transcendental experience of the difference between language and speech, which first opens the space of history. (1978, p. 52).
\end{abstract}

\footnotetext{
${ }^{16}$ Recollected by Waissman in 1929, the paragraph was first published in 1965 in Philosophical Review (LXXIV, pp. 3-27) as an Appendix to his Lecture on Ethics, conference given in the association called The Heretics. The reference to Heidegger that opens the paragraph originally entitled $Z u$ Heidegger was censored (VOLPI, 2006, p. 214).
} 
Although in-fancy (speech's absence) is not merely a chronological stage for Agamben, we find a similar interest in Wittgenstein. In fact, he opens his Philosophical Investigations reflecting on the part of Agustine's Confessions (Book I, 1.8.13) that describes the passage from infancy into a first language. $\mathrm{He}$ analyzes the Augustinian notion of learning a language by ostensive definitions, which leads to the misleading idea that meaning is the object for which a word stands, which only can be the case in imaginary "primitive languages" 17 and presupposing that the person already has a language but not that one (1958). In this book, Wittgenstein returns many times to the way in which a child is trained in the different uses of language or in learning mathematics, in a passage from imitation to understanding. Although he does not arrive to a strong conclusion on the matter, some implications interests us here that will be further developed by Agamben: the idea that infants must learn language to enter our human world, that language is the vehicle of thought and that it grounds the community through shared meanings.

Then, both for Agamben's ontological and for Wittgenstein's pragmatic approach, the acquisition of language is to be made: it is a game we have to learn how to play without knowing its rules in advance, but we need to apply those implicit rules in order to make our speech and actions meaningful to others. For both authors, the Homo sapiens has to acquire language, which in turn constitutes it as human. However, for Agamben this subtle gap between human beings and language implies that we have the potentiality not to become humans or even to fall out of humanity by political interventions, as with the Musselmann of the Nazi Lager that loses his capacity to speak and to be in the world. That is why in Remnants of Awschwitz Agamben reflects on the witness as a threshold between the human and the inhuman, who speaks on condition of its own impossibility, showing the specificity of the human subject. Reflecting on the ethical character of the witness, he returns to infancy to avoid the negative foundation presupposed by metaphysics, affirming that "[...] the human being is a speaking being only because it is capable of not having language, that is, "because it is capable of its own in-fancy»" (1998, p. 146). If this is the case, we might say that infancy is the non-human side of the human. But whereas the infant implies a transcendental possibility of a mute experience, the Musselman represents the dramatic figure of the inhuman within (post)history, the bare life produced by sovereign (bio)power. This inhumanity can also be grasped from 'the primitive language hypothesis'

${ }^{17}$ Of which Garver (1994) affirms that they are not human languages at all. 
developed by Wittgenstein, showing that human language is not merely a set of conditioned reactions to some words - like the Musselman's reaction to the SS orders - but a complex myriad of language-games that are meaningful for a specific form of life.

Continuing this analysis of the relation between language, world, ethos and (human) existence, Agamben returns once again to the Tractatus in "The Irreparable", the last part of The coming community (1990), as a comment to $\$ 6.44$ of Wittgenstein's text ("Not how the world is, is the mystical, but that it is") and $\$ 9$ of Heidegger's Sein und Zeit that issues the analytic of Dasein. ${ }^{18}$ Agamben's reading of that passage of the Tractatus concludes that there is no possible difference between essence and existence and that the existence within the world is divine. Together with Heidegger, for whom the essence of Dasein lies (liegt) in its existence and its ontological condition is that of being-in-the-world, ${ }^{19}$ Wittgenstein was also making possible to think this completely profane condition of the world, in which we ek-sist, which means - for Agamben - that the world itself is divine, that the possibility of salvation takes place within the world, in its being such, and that the world, as irreparably profane, is God. ${ }^{20}$ Irreparable - Agamben continues - is not essence or existence, substance or quality, possible or necessary. It is not a modality of being but the being that is its modalities. Is not such, but it is the such (1990, p. 77-79).

This ontological assumption of the coincidence between being and its modalities in-the-world is intended to be at the same time an epochal response. In the same sense that Wittgenstein was perceived by Pitkin (1972) as a philosopher concerned with the 'modern predicament' and the 'death of god', Agamben's idea that our form-of-life is irreparably profane has to do with the need to get rid of theological dispositifs of power over life (AGAMBEN, 1995, 2007): we must profane them, inventing new uses. While in secularization the

\footnotetext{
${ }^{18}$ Among the scholars who explored the relationship between Heidegger and Wittgenstein are K-O. APEL (1967), Karsten HARRIS (1968), Edward MINAR (2001), Franco VOLPI (2006) and Richard RORTY (1993).

${ }^{19}$ Agamben (2012) will later deconstruct this notion as part of the ontology of operativeness which conflates being and praxis.

${ }^{20}$ Which reminds Spinoza’s TractactusTheologico-Politicus. Similarly to Spinoza, Wittgenstein affirms in his Tractatus that the world (i.e. the totality of facts) is everything that is the case and in $\$ 5.621$ that the world and life are one. According to Kishik (2008), completing the notion of Deus sive natura we can see life as everything that is the case: Natura sive Vita. Therefore, Wittgenstein would move from the relation between language and world to that of language and life, which is crucial in Agamben's thought.
} 
power relation implied in the term or practice remains operative, in profanations new uses are invented for those institutions. That is the reason why profanation, game and use will be key notions for Agamben in his later developments. Notions that resemble Wittgenstein's language-games: not a petrified set of rules we learn and apply — like Agamben misinterpreted once (1978, p. 51) —, but a moving edifice which is pushed forward by our uses. In a kind of linguistic profanation, Wittgenstein brings "[...] words back from their metaphysical to their everyday use” (WITTGENSTEIN, 1958, p. 116).

These assertions on the relation between world's profanity, language (as human's second nature) and life (the Faktizität of existence) help us understand what is at stake for both authors in the concept of form-of-life. For Wittgenstein, as we saw, it allows to think the specificity of human life and the difference among its forms. At the same time, it is crucial to grasp how we use language. For Agamben, this notion is opposed to bare life. If bare life is the produce of biopolitics until today, form-of-life is the key notion of the coming politics.

\section{AgAMBEN'S POTENTIALITIES: BARE LIFE AND FORM-OF-LIFE}

As we know, Agamben has thought biopower in its ontological condition. Linking it to Carl Schmitt's theory of sovereignty which essence is the state of exception, Agamben conceives biopolitics as an originary relation of abandonment by which sovereign power creates bare life through the inclusive exclusion of the zoé (biological life) in the polis. In this sense, sovereignty is reduced to the relationship between nomos and bare $\operatorname{life}^{21}$ and, at the same time, its logic of exception can be traced back to the very birth of politics. So, biopower does not relate to a form of life but to the bare life of the homo sacer, who, according to the archaic Roman law, one could kill without committing homicide or celebrating a sacrifice (1995). In this context, formof-life, hyphened to stress the inseparability of life from its form, is the notion with which Agamben will try to think new forms of (non)relation between zoé and bios in order to think ethics and politics beyond the Law.

${ }^{21}$ Every "political" concept in Agamben has its ontological counterpart. For instance, bare life corresponds to ón haplos (pure being) and the sovereign ban is related to the abandonment of Being by beings. For this philosopher, ontology and politics are not autonomous realms: in order to think politics anew, it is necessary to rethink metaphysics and, within it, potentiality and actuality. 
These thesis on the production of bare life derive from certain presuppositions on the relationship between life and language: the way in which phoné, common to humans and animals (as zoè), is articulated in lógos (bios) also implies a relation of exception, in which a pair of terms is articulated in order to be later severed and sublated by one of them. In this sense, if the biopolitical machine of sovereign power separates zoé from bios, and the anthropological machine severs phoné from logos, giving birth to bare life, a form-of-life is a life that can never be separated from its forms, in which it is impossible to isolate a bare life (2000a, p. 3-4). A life in which potentiality and impotentiality coincide and language communicates without any unspeakable remainder.

A life that cannot be separated from its form is a life for which what is at stake in its way of living is living itself... It defines a life -human lifein which the single ways, acts, and processes of living are never simply facts but always and above all possibilities of life... Each behavior and each form of human living is never prescribed by a specific biological vocation, nor is it assigned by whatever necessity; instead $[\ldots]$ it always retains the character of a possibility; that is, it always puts at stake living itself. That is why human beings $[\ldots]$ are $[\ldots]$ the only beings whose life is irremediably and painfully assigned to happiness. But this immediately constitutes the form-of-life as political life [...] Political power as we know it, on the other hand, always founds itself -in the last instance- on the separation of a sphere of naked life from the context of the forms of life. (2000a, p. 4).

This long passage condenses many important Agambenian theses and stresses the immediate political character of human life, since it is in itself related to potentiality and language. Undeniably, Agamben's ontology and its implicit anthropology privileges (im)potentiality. He recovers Aristotle's assertion against the Megarians that potentiality of doing something is also the potentiality of not doing it, from which Agamben concludes that a potentiality needn't resolve itself into actuality. To act is to negate the potentiality of not doing or being something; so to act can be thought as not not-doing or being something $\left(1995,1^{\text {st }}\right.$ Part, $\left.\$ 3.3\right)$. In this sense, rephrasing Wittgenstein's amazement of the existence of the world, Agamben maintains that "[w]hat is astonishing is not that something was able to be, but that it was able to not not-be". (1993b, p. 103)

According to Agamben, our form-of-life is characterized by a generic mode of potentiality that is not exhausted in the transitus de potentia ad actum 
(1995, p. 40). The human being is a sabbatical, inoperative animal whose life does not coincide with a predetermined form (2007). The human being is a political being, not because he has language and thus the notion of justice, but because he has no biologically predetermined task and is in search of happiness in the community. Happiness would imply the end of the divide between life and its form, and thus the end of sovereign power.

A political life, that is, a life directed toward the idea of happiness and cohesive with a form-of-life, is thinkable only starting from... the irrevocable exodus from any sovereignty. The question about the possibility of a nonstatist politics necessarily takes this form: Is today something like a form-of-life, a life for which living itself would be at stake in its own living, possible? Is today a life of power available? (2000a, p. 8-9).

In this passage we see the political implications of form-of-life. It rejects sovereignty in order to enable the emergence of the coming community for which no negative foundation, no identity or subject, can work. A messianic community in which the Law is deactivated (katargein) and the exposure of whatever singularities should disengage from sovereignty, to affirm co-eksistance as such, with no presuppositions.

Similarly, in Wittgenstein's writings, community doesn't mean sharing and appertaining as an additional quality to already constituted subjects since the link between them is not contractual but one of mutual exposure. Hence, once again, the importance of the way in which one learns a language, since it shows how one adheres to it as a condition of possibility for a community of sense (BORUTTI, 2000).

Back to Agamben, his notion of form-of-life is characterized by the potentiality of thought. Indeed, beyond onto-theology that privileges beingin-act, thought implies not only specific objects but also pure potentiality, since it is not fully consummated in its own execution but rather increases its own potentialities while being in act. Thought is a figure of inoperativeness and Gelassenheit: it is an act, but not a work, since it does not produce or transform any-thing. It lets things be. It is also a means without ends, in which life and its form coincide:

I call thought the nexus that constitutes the forms of life in an inseparable context as form-of-life. I do not mean by this the individual exercise of an organ or of a psychic faculty, but rather an experience, an experimentum that has as its object the potential character of life and of human intelligence. "To 
think does not mean merely to be affected by this or that thing, by this or that content of enacted thought, but rather at once to be affected by one's own receptiveness and experience in each and every thing that is thought a pure power of thinking" [...] Only if I am not always already and solely enacted [...] only if, in other words, there is thought only then can a form of life become, in its own factuess and thingness, form-of-life, in which it is never possible to isolate something like naked life. (2000a, p. 9).

Language and thought constitute us as potential beings, they characterize our im-potential form-of-life. Whereas biopower isolates life from its form, reducing the human being to its biological dimension, the common experience of thought enables the re-articulation of phoné and logos, bios and zoé, into a form-of-life. Whereas Aristotle distinguishes bios politicos and theoretikos and signals the solitude of the latter, Agamben is pointing that bios theoretikos is in itself politicos since thought and language are the common and take place in-common. At stake here is the Averroist notion of one possible intellect common to human beings, Dante's multitude and the Marxist notion of General Intellect ${ }^{22}$ :

The experience of thought that is here in question is always experience of a common power. [...] Among beings who would always already be enacted, who would always already be this or that thing, this or that identity, and who would have entirely exhausted their power in these things and identities- among such beings there could not be any community but only coincidences and factual partitions. We can communicate with others only through what in us as much as in others has remained potential, and any communication [...] is first of all communication not of something in common but of communicability itself. [...] That is why modern political philosophy does not begin with classical thought, which had made of contemplation, of the bios theoreticos, a separate and solitary activity... but rather only with Averroism, that is, with the thought of the one and only possible intellect common to all human beings, and, crucially, with Dante's affirmation in De Monarchia of the inherence of a multitude to the very power of thought [...] Intellectuality and thought are not a form of life among others in which life and social production articulate themselves, but they are rather the unitary power that constitutes the multiple forms of life as form-of-life. (2000a, p. 9-10)

\footnotetext{
${ }^{22}$ This notion has inspired the theory of Immaterial Labor and the Multitude in authors such as Virno, Lazzarato, Negri and Hardt. In this work, Agamben is near to later developments of these authors, except for their thinking of constituent power outside sovereignty.
} 
Although these assertions are far from Wittgenstein's developments, language and thought also frame in his theory the constitution of a community of sense. Indeed, Hardt \& Negri ponder the importance of Wittgenstein's notions of form of life and language games to rethink the common as a shared experience of a multitude of intelligences that do not strive to posit a transcendental foundation for sharing:

\begin{abstract}
Wittgenstein's concepts manage to evade on one side individual, haphazard experience and, on the other, transcendental identities and truths, revealing instead, between or beyond them, the common. Language and language games, after all, are organizations and expressions of the common, as is the notion of a form of life. Wittgensteinian biopolitics moves from knowledge through collective practice to life, all on the terrain of the common. (2009, p. 121-22).
\end{abstract}

Far from any relativistic, anthropological and cultural reading of form of life as lifestyles, Agamben and Negri are not theorizing the impossibility to transcend our culture as a relatively closed entity or affirming the need to tolerate diverse 'ways of life'. That is precisely the logic of sovereign power (and liberal multiculturalism), since the state is founded on the recognition and representation of diverse identities. On the contrary, the coming community thought by Agamben implies the pure exposition the co-incidence of 'whatever singularities' (a multitude of singularities in Negri's theory) without identity (1990).

For Agamben, this unitary power of thought and language is expropriated by contemporary capitalism in the form of the Spectacle (Debord). It expropriates language itself, the human linguistic nature that Heraclitus identified as the Common, alienating us from our linguistic being. However, that expropriation enables us to experience our linguistic nature as such. In this sense, the destruction of traditions and beliefs that the Spectacle produces, revealing the pure void of communicability, is the precondition of a community without presuppositions and without state. ${ }^{23}$ (1990: \$18) That is why the opposition between man and citizen is outdated: citizenship itself, juridical personhood, forms of life understood as social identities are all based

${ }^{23}$ This logic is quite Unheimlich when we get to the notion of the Musselmann revealing, in his bare life, the true face of the human as a remnant. Many passages in Agamben seem to point that it is precisely here, in this pure exposure of a life without any presuppositions, that we find the figure of the coming community in its radical opposition to the state and its radical abandonment, as in the case of Tiananmen in The Coming Community. 
on the preexistence of bare life (AGAMBEN, 2000a). In this sense, to think a form-of-life at the height of the political idea of happiness implies a complete rethinking of the foundations of political philosophy and philosophical anthropology:

The "happy life" on which political philosophy should be founded thus cannot be either the naked life that sovereignty posits as a presupposition so as to turn it into its own subject or the impenetrable extraneity of science and of modern biopolitics that everybody today tries in vain to sacralize. This "happy life" should be, rather, an absolutely profane "sufficient life" that has reached the perfection of its own power and of its own communicability - a life over which sovereignty and right no longer have any hold. (2000a, p. 114-15).

As we can see, the goal of politics remains leading a happy life, as it was for Greek thought, but for Agamben it is only possible beyond Right and Sovereignty. For Agamben, sovereign and oikonomical power are secularized forms of a theological content, intimately connected to the sacralization of life, which implies its inner division and its exposure to a power of death over it. Profanation, on the contrary, is a way of deactivating this kind of subjection to a transcendent power, freeing singularities from any relation to sovereign ban and Law.

In this sense, a form-of-life beyond the Law implies actualizing our own manner (1993b, p. 29) and potentialities. A use of the self (Mills) that does not treat existence as a property. An ethics in which being its own way of being is the only possibility for happiness. An Ethos, a "use", which for both authors makes possible to think a community of singularities where life coincide with its form.

\section{USUS PAUPER AND FORM-OF-LIFE}

As mentioned above, Agamben and Wittgenstein link the notion of form-of-life to that of use. Wittgenstein developed his theory of languagegames analyzing the way we use language in everyday life and describing formal logic as senseless with regards to this matter. In Agamben, the notion of use is crucial to understand his ethical thought. Agamben recovers Paul's notion of chrésis (use) and the Franciscan notion of usus pauper, a form of use of the goods necessary to life and a use of our selves outside the relations 
of property and the Law in general. In fact, developing a genealogy of the notion of form-of-life (2011), it is ultimately to the experience of Franciscan monasteries that Agamben links these notions, bearing in mind at least two points of Wittgenstein's thought in order to think a new relationship between norms and life.

The first reference alludes to the famous reflection on what it means to obey a rule. For Wittgenstein, to follow a rule, as a social practice, and to believe to be following a rule is not to follow a rule: it is not possible privatim (1958, \$202). Agamben uses this idea to characterize the relationship between norm and life in the monasteries. For Agamben the decisive point is that the form of life at stake there is a koinos bios, a common life. To follow a rule implies a community and a habit (2011, p. 77). The coenobium appears as a form of community of life in which life is the constitutive element, a sort of constituent power with respect to any rule.

Accordingly, the second point that the Italian takes from Wittgenstein in this book is the analysis of constitutive norms, i.e. norms that do not prescribe or regulate a certain act or state of affairs but give place to them. Agamben defines a form of life as the ensemble of constitutive rules that defines it. Rules are created by the monk's form of life where norms and life enter a zone of indifference that gives place to a third term that the Franciscans will call "use" (p. 92). According to Agamben, Wittgenstein's idea of a constitutive rule neutralizes the representation of the rule as the application of a general principle to a single case:

The cenobitic project, by shifting the ethical problem from the level of the relation between norm and action to that of form of life, seems to call into question the very dichotomy of rule and life, universal and particular, necessity and liberty, through which we are used to comprehending ethics. (2013, p. 72).

As we can see, this notion of form-of-life implies an immanent relationship between norms and life which opposes the imposition of a transcendent Law. As a paradigm that expresses this idea, Agamben considers the Franciscan notion of usus pauper and the altissima paupertas as the form of life that emerges when all the previous forms of life of the West are exhausted. According to Agamben, it was not the rule but life that was at stake for the Franciscans. They didn't intend to offer a new doctrine but a form of life (p. 118) which implied a renunciation to property and to Right (abdicatio 
iuris). A life outside the Law and defined by poverty, by usus, in opposition to dominium. However, Agamben points out that since the Franciscans defined use in juridical and negative terms - in opposition to property - they have not developed a theory of use. This would be the task of the coming philosophy: to think use as a form-of-life beyond the Law and the paradigm of operativeness that has always been dominant in the West.

\section{CONCLUDING REMARKS}

In the previous sections, I tried to give an account of the ambiguities of the notion of form of life through a brief genealogical reconstruction that enables both a naturalistic and a cultural reading of it. I suggested that Wittgenstein and Agamben help us overcome that dichotomy putting at stake the specificity of the human 'form of life' without denying the plurality of forms within it.

In so doing, they illuminate what we have in common as humans: our linguistic acquired "nature", our ability to think, and the fact that we need to be in common in order to think and speak. For both, our form-of-life, our historical existence, takes place within language. However, we have to enter its realm. Hence, infancy becomes crucial for both authors, since it expresses the openness of our potentialities, the fact that language, our "nature", must be acquired. In this sense, the greatness of human's own potentiality is measured by the abyss of impotentiality (1999, p. 128).

Indeed, we saw that, according to Agamben, human beings are those animals that are capable of their own impotentiality. Far from any biological determinism, the human animal, who has language as its specific trait, can also be politically reduced to merely biological life, as in the concentration camps, revealing the human as an indestructible remnant that can be infinitely destroyed (2000b, p. 55). The concentration camp is the space where the human, rendered speechless, touches its own inhumanity, and the witness must give account of the unspeakable to subjectify himself ethically. For Agamben, "[...] the key difference is between biological life, which lives only to maintain itself, and human poetic life, which lives in order to create forms. Humans, therefore, should be regarded those beings who may or may not give themselves a world" (COLEBROOK, 2008, p. 109). 
Also Wittgenstein shows that language and therefore any commonality becomes impossible when only commands are expressed. At the same time, he shows that our relation to language implies thinking our specific form of life beyond any biological or cultural determinism. He speaks of natural history because the specificity of the human regarding the rest of living beings is the capacity to use language, and our capacity to hope or to deceive and know to be hoping or deceiving, a certainty that is embedded in our form of life as "something animal" (1972, \$357 - \$359). For Wittgenstein, human beings can only become such in relation with others, learning a language and communicating through it, sharing a form of life.

In this sense, while Agamben is interested in the possibility to appropriate and expose our own linguistic-being, Wittgenstein thinks the conditions of possibility for a language to work and be meaningful for intersubjective communication. These conditions are immanent to that same language and our uses, to our form of life.

Last but not least, both authors link our form of life to forms of use. While Wittgenstein is concerned with the way we use language-games with their rules and the way we learn how to "play» with them, Agamben's positive project focuses on profanations or free use of what was sacred and unattainable, foreseeing a moment in which we will play with the Law like kids with old objects, rendering the Law inoperative and inventing new uses.

In this sense, the notion of form-of-life allows both authors to think the common beyond traditional dichotomies such as universalism/particularism, necessity/accident, bios/zoé, physis/nomos. A form of life related to new uses, habits and institutions.

At first glance, form-of-life cannot be translated easily into politics, because it is a key notion for a community that realizes itself through inoperativeness (Agamben) and in the use and transmission of language, in the reproduction of our 'complicated form of life' (Wittgenstein). However, Agamben writes in the post-face of the 2001 Italian version of The coming community that inoperativeness [inoperosità] and de-creation [decreazione] are the paradigm of the coming politics. Inoperativeness means katargein, an operation in which the how substitutes the what, in which life without form and forms without life coincide in a form-of-life (1990, p. 92-93).

Then, as we can see, whereas Wittgenstein's main scope was limited to describe and analyze the way we use language, which is embedded in a 
form of life, Agamben's notion of form-of-life is a normative one. It calls for the interruption of operativeness, an interruption of power dispositifs such as the anthropological and governmental machines, through a new use of the world and the self in order to enable a life in common in which happiness can become once again a political possibility.

SAIDEL, Matías Leandro. Forma(s)-de-vida. A leitura de Agamben sobre Wittgenstein e os usos potenciais de uma noção. . Trans/Form/Ação, Marília, v. 37, n. 1, p. 163-186, Jan./ Abr., 2014

RESUMO: Giorgio Agamben e Ludwig Wittgenstein parecem ter muito pouco em comum: o primeiro se ocupa de questóes ontológicas tradicionais, enquanto o segundo estava interessado na Lógica e na linguagem corrente, evitando os problemas metafísicos como algo de que não podemos falar. No entanto, ambos partilham um conceito crucial para seus projetos filosóficos respectivos: forma de vida. Este artigo tento mostrar que, apesar de seus diferentes enfoques e objetivos, a noção de forma de vida é fundamental no momento de pensar a ética e a vida em-comum. Abordando a existência humana em sua relação constitutiva com a língua, essa noção desconstrói dicotomias tradicionais como bios e zoe, o cultural e o biológico, permitindo-lhes pensar uma vida que não pode ser separada de suas formas, e reconhecendo o caráter comum do logos como o traço específico da existência humana. Através de uma leitura analógica entre ambos quadros teóricos, sugiro que a noção de forma-de-vida, elaborada por Wittgenstein para abordar a produção humana de significados, tornase o conceito-chave do pensamento afirmativo de Agamben, já que nos permite considerar o comum ontologicamente em sua relação com as potencialidades humanas e vislumbrar um uso novo e comum do mundo e de nós mesmos.

PALAVRAS-CHAVE: Agamben. Wittgenstein. Forma de vida. Potencial. Língua. Comunidade.

\section{WORKS Cited}

AGAMBEN, Giorgio. The Highest Poverty: Monastic Rules and Form-of-Life. Translated by Adam Kotsko. Stanford: Stanford Univ. Press, 2013.

AGAMBEN, Giorgio. Opus dei. Archeologia dell'ufficio. Torino: Bollati Boringhieri, 2012.

AGAMBEN, Giorgio. Altissima povertà. Regole monastiche e forma di vita. Vicenza: Neri Pozza, 2011.

AGAMBEN, Giorgio. Il regno e la gloria. Per una genealogia teologica dell'economia e del governo. Homo sacer 2,2. Vicenza: Neri Pozza, 2007.

AGAMBEN, Giorgio. Profanazioni, Roma: Nottetempo, 2005. [Jeff Fort (Trans). Profanations. New York: Zone Books, 2007].

AGAMBEN, Giorgio. L'aperto. L'uomo e l'animale. Torino: Bollati Boringhieri, 2002. [Kevin Attell (Trans). The Open: Man and Animal. Stanford University Press, 2004]. 
AGAMBEN, Giorgio. Mezzi senza fine. Note sulla politica. [Vincenzo Binetti and Cesare Casarino (Trans.) Means Without Ends: Notes on Politics. Minneapolis: University of Minnesota Press, 2000a].

AGAMBEN, Giorgio. Il tempo che resta. Un commento alla Lettera ai Romani. Torino: Bollati Boringhieri, 2000b [2008].

AGAMBEN, Giorgio. La potenza del pensiero. [Daniel Heller-Roazen (Ed. and Trans.). Potentialities: Collected Essays in Philosophy. Stanford University Press, 1999].

AGAMBEN, Giorgio. Quel che resta di Auschwitz. Torino: Bollati Boringhieri, 1998. [Daniel Heller-Roazen (trans.) Remnants of Auschwitz: The Witness and the Archive. New York: Zone Books].

AGAMBEN, Giorgio. Homo Sacer: Il potere sovrano e la nuda vita. Torino: Einaudi, 1995. [Daniel Heller-Roazen (Trans). Homo Sacer: Sovereign Power and Bare Life. Stanford: Stanford University Press, 1998].

AGAMBEN, Giorgio. Bartleby o della cotingenza. In: AGAMBEN, G.; DELEUZE, G. Bartleby. La formula della creazione. Macerata: Quodlibet, 1993a [2006].

AGAMBEN, Giorgio. The coming community. Michael Hardt (trans.). Minneapolis: University of Minnesota Press, 1993 b.

AGAMBEN, Giorgio. La comunità che viene. Torino: Bollati Boringhieri, 1990 [2001].

AGAMBEN, Giorgio. Un' idea di Giorgio Agamben. Intervista con A. Sofri, Reporter, 9-10, p.32-33, nov. 1985.

AGAMBEN, Giorgio. Il linguaggio e la morte. Un seminario sul luogo della negatività, Torino: Einaudi, 1982.

AGAMBEN, Giorgio. Infanzia e storia. Torino: Einaudi, 1978 [Liz Heron (Trans). Infancy and History: The Destruction of Experience. New York: Verso Books, 1993].

APEL, Karl-Otto. Wittgenstein y Heidegger: La pregunta por el sentido del ser y la sospecha de falta de sentido contra toda metafísica, Traducción de Bernabé Navarro, en Dianoia. Anuario de filosofía. México: F.C.E., p. 111-148, 1967.

BORUTTI, Silvana. Wittgenstein e l'impolitico, in: ESPOSITO, R.; GALLI, C.; VITIELLO V. (Ed..) Nichilismo e Politica. Roma: Laterza, 2000.

COLEBROOK, Claire. Agamben: Aesthetics, Potentiality, and Life. South Atlantic Quarterly 107:1, Winter 2008

ESPOSITO, Roberto. Bios. Biopolitica e filosofia.Torino: Einaudi, 2004.

GARVER, Newton. This complicated form of life. Chicago: Open Court, 1994.

HANFLING, Oswald. Wittgenstein and the Human Form of Life. London - New York: Routledge, 2002. 
HARDT, Michael; NEGRI, Antonio. Commonwealth. Cambridge: Harvard University Press, 2009.

KISHIK, David. Agamben and the Coming Politics. (To imagine a form of life, II). London - New York: Continuum, 2012.

KISHIK, David. Wittgenstein's Form of Life. (To Imagine a Form of Life, I). London - New York: Continuum, 2008.

NIETZSCHE, Friedrich. Götzen-Dämmerung. 1888. At http://www.nietzschesource. org/\#eKGWB/GD. Twilight of the Idols and the Antichrist. Thomas Common (Trans.). Digireads, 2009.

O'CONNOR, Peg. Morality and our complicated form of life. Feminist Wittgensteinian Metaethics. Pennsylvania State University Press, 2008.

PADILLA GÁLVEZ, Jesús; GAFFAL, Margit (Ed.). Forms of Life and Language Games. Heusenstamm: Ontos, 2012.

PITKIN, Hanna. Wittgenstein and Justice. On the Significance of Ludwig Wittgenstein for Social and Political Thought. Berkeley: University of California Press, 1972.

TUNANDEN, Ola. Swedish-German geopolitics for a new century Rudolf Kjellén's 'The State as a Living Organism'. Review of International Studies, 27, 451-463, 2001.

VOLPI, Franco. La maravilla de las maravillas: que el ente es. Wittgenstein, Heidegger y la superación "ético-práctica” de la metafísica, Revista Tópicos, 30, p. 197-231, 2006.

WITTGENSTEIN, Ludwig. On Certainty. G. E. M. ANSCOMBE, G.E.M.; VON WRIGHT, G.H. (Ed.). New York: Harper,1972.

WITTGENSTEIN, Ludwig. A Lecture on Ethics (1929). The Philosophical Review, Vol. 74, no. 1, p. 3-12, jan. 1965. Stable URL: http://www.jstor.org/stable/2183526.

WITTGENSTEIN, Ludwig. Philosophical Investigations. Translated by G. E. M. Anscombe, Blackwell, 1958 [1999].

WITTGENSTEIN, Ludwig. Tractatus Logico-Philosophicus, 1922 [Trans C.K. Ogden. New York: Barnes \& Noble, 2003].

WITTGENSTEIN, Ludwig. Wittgenstein Source - Wittgenstein Archives at the University of Bergen (WAB), available at wittgensteinsource.org.

Submissão: 27/03/2013

Aceito em: 25/05/2013 